\title{
Planting Date and Biculture Affect Sunn Hemp Productivity in the Midwest
}

\author{
James K. Stute ${ }^{1}$ \& D. Esther Shekinah ${ }^{2}$ \\ ${ }^{1}$ Research Director, Michael Fields Agricultural Institute, East Troy, Wisconsin 53120, USA \\ ${ }^{2}$ Research Scientist, Michael Fields Agricultural Institute, East Troy, Wisconsin 53120, USA \\ Correspondence: D. Esther Shekinah, Michael Fields Agricultural Institute, East Troy, Wisconsin 53120, USA. \\ E-mail: eshekinah@michaelfields.org
}

Received: January 8, $2019 \quad$ Accepted: January 25, $2019 \quad$ Online Published: February 14, 2019
$\begin{aligned} & \text { doi:10.5539/sar.v8n2p26 } \\ & \text { URL: https://doi.org/10.5539/sar.v8n2p26 }\end{aligned}$

\begin{abstract}
Sunn hemp (Crotalaria juncea L.) is recommended as a warm season cover crop in the Midwest due to its ability to produce high levels of biomass and fix atmospheric nitrogen. It can also be grown in biculture with other cover crops to enhance overall ecosystem services. Two field experiments were conducted over four growing seasons $(2014$ - 2017) in Wisconsin on a forest derived Fox silt loam (Fine-loamy, mixed, mesic Typic Hapludalfs) under organic certification to determine the effect of planting date on sunn hemp dry matter yield, $\mathrm{N}$ and $\mathrm{C}$ addition and to determine the effect of species ratio in a biculture with sorghum-sudan [Sorghum bicolor (L.) Moench] on the same output variables as well as seed cost and the related per unit cost of production. Planting dates significantly affected all biomass yield variables, which declined linearly from the initial date and appear related to growing degree accumulation. Regression analysis revealed a biomass yield decline of $1.3 \%$ per day $\left(8.9 \%\right.$ week $\left.^{-1}\right)$ in relative yield, and $0.90 \mathrm{Mg} \mathrm{day}^{-1}\left(0.61 \mathrm{Mg}\right.$ week $\left.^{-1}\right)$ in actual yield. In biculture, sunn hemp grown in a planting ratio of 50:50 with sorghum-sudan maximized $\mathrm{N}$ addition through nitrogen fixation and added $\mathrm{N}$ from dry matter, without a significant difference in the dry matter recorded. Analysis of seed cost data revealed that as the ratio of sunn hemp in the planting mixture decreased, the cost per hectare decreased. The cost of production per unit of DM, N, C and $\mathrm{CO}_{2}$ equivalent at this planting ratio were $7.08 \$ \mathrm{Mg}^{-1}, 0.57$ $\$ \mathrm{~kg}^{-1}, 17.51 \$ \mathrm{t}^{-1}$ and $4.78 \$ \mathrm{t}^{-1}$ respectively. In pure culture, early planting dates (June $15^{\text {th }}$ to July $15^{\text {th }}$ ) are recommended for sunn hemp, and in biculture, a planting ratio of 50:50 with sorghum-sudan could serve Midwestern producers well by reducing per unit cost of biomass production.
\end{abstract}

Keywords: biculture, biomass, carbon, cover crop, nitrogen, organic, planting dates, sorghum-sudan, sunn hemp

\section{Introduction}

Cover cropping is a conservation practice which protects soil while providing other benefits like weed suppression, nitrogen $(\mathrm{N})$ fixation, increased soil organic matter (SOM) and improved soil health. Several cover crops are effective under Midwest conditions; however their ability to produce high quantities of biomass (DM) in a relatively short time is severely limited (Esther \& Stute, 2018). Selection of a legume as a cover crop is desirable because of $\mathrm{N}$ fixation, but as a group, they may be less productive than non-legumes in terms of biomass production, and their contribution to SOM is questionable due to their relatively low C:N ratios, leading to rapid decomposition. Creamer \& Baldwin (2000) and Schomberg et al. (2007) found that several legumes can be successfully grown as warm season cover crops to provide both biomass and nitrogen. $\mathrm{N}$ accumulation can be highly variable depending on the environment, legume selection, planting date, management and termination (Balkcom \& Reeves, 2005; Balkom et al., 2011).

Sunn hemp, a tropical legume, is a potential warm season cover crop for the Midwest. In the southern U.S. large biomass yields are reported to be produced in a relatively short time (Price et al., 2012). Sunn hemp provides weed suppression due to rapid canopy development (Mosjidis \& Wehtje, 2011) which could contribute to early soil protection compared to other species. Price et al. (2012) reported that it can produce larger quantities of biomass within a shorter timeframe than winter legumes from the temperate zone. Average biomass yield of $9 \mathrm{t} \mathrm{ha}^{-1}$, produced in as little as 60 to 90 days has been reported in a 2-year study in Oklahoma (Warren et at., 2017). Results from Florida (Cherr et al., 2006) and Alabama (Mansoer et al., 1997) show yield of 5 to $8 \mathrm{Mg}^{-1}$ of biomass and an $\mathrm{N}$ addition of 135 to $150 \mathrm{~kg} \mathrm{ha}^{-1}$ produced within a 12-week period. As a warm-season species, 
it could fit well in several cropping situations such as summer fallow (including prevented plant acres or organic transition) as well as after the harvest of short season crops (Esther \& Stute, 2018). Sunn hemp is not able to produce viable seed in this climate eliminating the potential to volunteer in subsequent years (NRCS, 1999) and is reported to suppress nematodes (NRCS, 1999; Wang et al., 2002). We hypothesized that it may produce acceptable yield over a range of planting dates during the summer period.

Sunn hemp seed cost is high relative to other cover crop options which may make it a less desirable option for producers. Planting it with a compatible companion crop in biculture could reduce the seeding cost compared to pure stands. Sorghum-sudan [Sorghum bicolor (L.) Moench] is a commonly used, productive summer cover crop and is unequaled for adding organic matter to worn out soils (SARE.org). It also produces higher biomass yield, rapid canopy development and provides greater weed suppression than other summer annuals (Stute unpublished). We hypothesize it can compete well with sun hemp, provided they are of equal height; and will perform well using $\mathrm{N}$ fixed by the legume without any additional $\mathrm{N}$ input. Hence, they may be best suited as companion crops to provide complementary benefits, reduce sunn hemp seed cost, and the cost of production for output variables [DM; $\mathrm{N}$; and carbon $(\mathrm{C})]$ based on seeding rate and seed cost.

Information on growing sunn hemp either solely or in biculture with sorghum-sudan for its value as a cover crop is lacking for the Midwestern United States. Sunn hemp is not widely grown in the Midwest but could be highly beneficial here for the afore-mentioned reasons. There is a lack of general agronomic information about its culture, and quantification of its effect on the ecosystem. Planting date effects, the optimum date for planting and impact of advancing date are relatively unknown. When followed by a high $\mathrm{N}$ demand crop, the associated benefits (such as fixed $\mathrm{N}$ ) may provide greater agronomic service to the following crop apart from the traditional cover crop benefit of soil conservation. Therefore, two experiments were conducted with the objectives: (1) to determine the effect of planting date on DM yield, $\mathrm{N}$ and $\mathrm{C}$ addition and (2) determine the effect of species ratio in a biculture on the same output variables.

\section{Materials and Methods}

Two field experiments were conducted from 2014 to 2017 near East Troy, Wisconsin (42.7488232, 88.4432654). This certified organic site has long-term organic history, transitioning in the 1980's and certified by Stellar Certification Services Inc. (Philomath, OR) under USDA National Organic Standards since 2004. The soil type is a forest derived Fox silt loam (Fine-loamy, mixed, mesic Typic Hapludalfs). Soil was sampled to a depth of 15 $\mathrm{cm}$ prior to planting and analyzed for routine fertility by the University of Wisconsin Soil Test Laboratory using standard procedures: organic matter, loss on ignition; P and K (Bray 1). Results are reported in Table 1.

Sunn hemp seed (vns, Pecter Seed Company, Fruitdale, AL) was pre-inoculated with a peat-based Bradyrhizobium product (N-DURE, Verdesian Life Sciences, Cary, NC) using a water and molasses solution as a sticker and allowed to dry. Seedbed preparation consisted of field cultivation just before planting. Both experiments were established with a 10-row plot drill ( $\mathrm{H}$ and $\mathrm{N}$ Equipment, Colwich, KS) with $19 \mathrm{~cm}$ row spacing, equipped with both bulk seed boxes and a cone-seed attachment. Seeding rate was adjusted using variable rate drives (Zero-max, Minneapolis, MN) on either unit. Seed was planted to a nominal $2.25 \mathrm{~cm}$ depth and furrows closed with press wheels. Final plot size in both experiments was $1.98 \times 5.17 \mathrm{~m}$. 
Table 1. Experimental dates and conditions

\begin{tabular}{|c|c|c|c|c|}
\hline & Year & & & \\
\hline Variable/ Date & 2014 & 2015 & 2016 & 2017 \\
\hline \multicolumn{5}{|l|}{ Initial Soil Test Levels } \\
\hline $\mathrm{pH}$ & 7.0 & 6.9 & 7.0 & 6.9 \\
\hline $\mathrm{OM}\left(\mathrm{g} \mathrm{kg}^{-1}\right)$ & 3.6 & 2.8 & 3.6 & 2.8 \\
\hline Phosphorus ( $\mathrm{mg} \mathrm{kg}^{-1}$ ) & 119 & 68 & 119 & 68 \\
\hline Potassium $\left(\mathrm{mg} \mathrm{kg}^{-1}\right)$ & 255 & 102 & 255 & 102 \\
\hline \multicolumn{5}{|l|}{ Planting Date } \\
\hline \multicolumn{5}{|l|}{ Experiment 1} \\
\hline 1 & & & 15-Jun & 15-Jun \\
\hline 2 & & 2-Jul & 1-Jul & 28-Jun \\
\hline 3 & & 16-Jul & 15-Jul & 18-Jul \\
\hline 4 & & 4-Aug & 1-Aug & 1-Aug \\
\hline 5 & & & 10-Aug & 16-Aug \\
\hline 6 & & & 1-Sep & 1-Sep \\
\hline \multicolumn{5}{|l|}{ Experiment 2} \\
\hline Planting Date & 30-Jun & 2-Jul & & 28-Jun \\
\hline First Frost & $10-$ Oct & $17-$ Oct & 13-Oct & 26-Oct \\
\hline Sampling Date & $10-$ Oct & 27-Oct & $14-\mathrm{Oct}$ & 19-Oct \\
\hline \multicolumn{5}{|l|}{ Precipitation $(\mathrm{mm})^{1}$} \\
\hline June (118) & 177 & 103 & 51 & 171 \\
\hline July (90) & 89 & 67 & 6 & 315 \\
\hline Aug. (92) & 87 & 147 & 85 & 46 \\
\hline Sept. (79) & 69 & 160 & 31 & 15 \\
\hline Oct. (61) & 53 & 17 & 10 & 119 \\
\hline Total (439) & 475 & 494 & 184 & 666 \\
\hline \multicolumn{5}{|c|}{ Growing Degree Day Accumulation $^{11}$} \\
\hline June & 502 & 506 & 541 & 535 \\
\hline July & 475 & 568 & 675 & 610 \\
\hline Aug. & 539 & 560 & 684 & 498 \\
\hline Sept. & 336 & 216 & 476 & 458 \\
\hline Oct. & 147 & 180 & 238 & 274 \\
\hline Total & 1,999 & 2,030 & 2,614 & 2,375 \\
\hline
\end{tabular}

${ }^{1}$ Values in parentheses are 15-year average monthly precipitation.

${ }^{11}$ Base $50^{\circ} \mathrm{F}$, maximum $86^{\circ} \mathrm{F}$.

\subsection{Effect of Planting Date (Experiment I)}

This study evaluated the effect of planting date on variables related to aboveground biomass yield: DM; N and C, and by calculation, $\mathrm{CO}_{2}$ equivalent. Planting dates were scheduled for 15-day intervals and are listed in Table 1 . Additional dates were included following 2015 to evaluate a longer period of the growing season. Seed was planted at a rate of $1.48 \times 10^{6}$ seeds ha ${ }^{-1}$ on a pure live seed (PLS) basis.

Aboveground biomass was sampled following a killing frost by hand cutting plants at ground level using a quadrat which yields an equivalent of $1.82 \mathrm{~m}$ of row. Whole-plant samples were weighed and chopped with a mobile chipper and subsamples dried at $60^{\circ} \mathrm{C}$ to a constant weight. Dried samples were ground to pass a $0.5 \mathrm{~mm}$ screen (Wiley \#4, Aurthor $\mathrm{H}$. Thomas Co. Philadelphia, PA) and analyzed for $\mathrm{N}$ and $\mathrm{C}$ by dry combustion using a Flash EA 1112 CN Automatic Elemental Analyzer (ThermoFinnigan, Milan, Italy). Carbon dioxide equivalent was calculated based on DM, C content and atomic mass.

The experimental design was a randomized complete block with three replicates. The 2016 and 2017 site-years had four replicates but one was lost in 2016 so the combined analysis uses three. Data were subject to analysis of variance procedures using proc ANOVA (SAS Inc, Cary NC) both combined over years to analyze year by date interactions as well by year due to unequal planting dates between years. Means were separated by a protected LSD at a 5\% level of probability. Data were pooled for regression analysis using proc GLM to determine growth curves. This data was transformed to relative yield by year using the greatest plot yield within a year as $100 \%$ 
(Yau \& Hamblin, 1994).

\subsection{Effect of Seeding Ratio in Biculture (Experiment II)}

This study evaluated the effect of sole seeded sunn hemp, sorghum-sudan cv "Special Effort", and biculture mixes of several compositional ratios on the same variables related to aboveground biomass yield as Experiment 1. Both sole seedings and biculture mixes were seeded at a rate of $1.48 \times 10^{6}$ seeds ha ${ }^{-1}$ (PLS basis) which is consistent with commercial recommendations for each species. Ratios included $100 \%$ for either in the case of sole seeding; 50:50\%; 67:33\% and 75/25\%, the latter two in both species combinations.

Aboveground biomass was sampled using the methods of Experiment I, either following a killing frost or when sorghum-sudan seeds appeared to approach maturity. In the case of mixes, plot samples were separated by species to determine the contribution of each to plot total. Samples were processed and analyzed identically to Experiment 1.

The experimental design was a randomized complete block with three replicates. Mix component data were combined by plot for measured variables and subject to ANOVA. Means were separated by a protected LSD at the $5 \%$ level of probability. Data for species contribution to treatment total are presented but not analyzed statistically because of the unbalanced design caused by the sole seeded treatments.

\section{Results and Discussion}

Precipitation and Growing Degree Day (GDD) data are shown in Table 1. Total growing season (June - October) precipitation was slightly above average in 2014 and 2015, 42\% of average in 2016 and $152 \%$ of average in 2017. Mean monthly precipitation during this study was similar to long-term site average but highly variable. July was the most variable (range 6-315 mm, SD 135) followed by June (51-177 mm, SD 59.9), September (15-160 mm, SD 64.9) and August (46-147 mm, SD 41.7). June and July variability are important to this study because it directly impacted 4 of the 6 seeding dates. Twenty sixteen June-July precipitation totaled $57 \mathrm{~mm}$ compared to the long-term average of $228 \mathrm{~mm}$. This coupled with relatively low precipitation in September impacted results of Experiment I discussed below.

Growing Degree Days (GDD) were calculated monthly and totaled for the season. Long term means for GDD accumulation are unavailable for this site so season totals are compared to 2014, the coolest year in which the 2 experiments were conducted. The years 2014 and 2015 were similar, 2016 and 2017 were warmer with GDD accumulations (\% of 2014) of 131 and 119 respectively. As with precipitation, June-July GDD is important in data interpretation. The years 2016 and 2017 were much warmer than previous years, yet had differential precipitation, 2016 warm and dry, 2017 warm and wet. Killing frost dates were similar to or later than the long term average occurrence between 1-10 October (National Weather Service, 2018).

\subsection{Biomass Yield}

Sunn hemp biomass yield and associated components from Experiment I are reported in Table 2. Data are presented as 2015 and combined 2016-2017 due to the unbalanced design (fewer dates in 2015), and combined years (2016-2017) since the year $\mathrm{x}$ date interaction was not significant. Biomass production was impacted by weather conditions and planting date. In general, biomass yield was greater in 2016-2017, but this was related to the lack of June planting date in 2015. Regression analysis of the combined data indicated a significant linear yield decline from mid-June, so the 2015 data does not represent full yield potential. In a combined analysis of dates 2-4, the year $\mathrm{x}$ date interaction was not significant and 2015 yield was comparable to 2016. 
Table 2. Effect of planting date on dry matter yield and related components

\begin{tabular}{|c|c|c|c|c|c|c|c|c|}
\hline \multirow[b]{2}{*}{ Date } & \multicolumn{2}{|c|}{ DM Yield } & \multicolumn{2}{|c|}{ N Content } & \multicolumn{2}{|c|}{ C Content } & \multicolumn{2}{|c|}{$\mathrm{CO}_{2}$ Equivalent } \\
\hline & 2015 & 2016-17 & 2015 & 2016-17 & 2015 & 2016-17 & 2015 & 2016-17 \\
\hline & \multicolumn{2}{|c|}{$-\mathrm{Mg} \mathrm{ha}^{-1}-$} & \multicolumn{2}{|c|}{ - $\mathrm{kg} \mathrm{ha}^{-1}-$} & \multicolumn{2}{|c|}{$-\mathrm{tha}^{-1}-$} & \multicolumn{2}{|c|}{$-\mathrm{tha}^{-1}-$} \\
\hline 1 & & 9.50 & & 137.9 & & 4.10 & 7.44 & 15.04 \\
\hline 2 & 4.30 & 7.39 & 46.7 & 118.4 & 2.03 & 3.11 & 5.50 & 11.39 \\
\hline 3 & 3.15 & 6.87 & 30.0 & 97.6 & 1.50 & 2.87 & 2.16 & 10.51 \\
\hline 4 & 1.26 & 3.49 & 28.0 & 74.5 & 0.59 & 1.45 & & 5.32 \\
\hline 5 & & 1.84 & & 42.8 & & 0.76 & & 2.80 \\
\hline \multirow[t]{2}{*}{6} & & 0 & & 0 & & 0 & 5.03 & 0 \\
\hline & & & & & & & 3.26 & \\
\hline Mean & 2.90 & 4.85 & 34.9 & 78.5 & 1.37 & 2.05 & & 7.51 \\
\hline \multirow[t]{2}{*}{$\operatorname{LSD}(0.05)$} & 1.87 & 2.20 & $\mathrm{~ns}$ & 41.7 & 0.89 & 0.98 & & 3.60 \\
\hline & & & & $r$ & 2 & 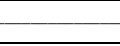 & & 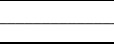 \\
\hline Year & & $<.0001$ & & $<.0001$ & & $<.0001$ & & $<.0001$ \\
\hline Date & 0.0261 & $<.0001$ & 0.4234 & $<.0001$ & 0.0260 & $<.0001$ & 0.0264 & $<.0001$ \\
\hline Year x Date & & 0.2371 & & 0.0678 & & 0.2240 & & 0.2233 \\
\hline
\end{tabular}

The impact of growing season on DM yield was evident in a combined analysis of dates 2-4 which had a significant year effect (P > F 0.0004). Mean DM yields of 7.61, 7.43 and $3.45 \mathrm{Mg} \mathrm{ha}^{-1}$ (data not shown) were observed in 2015, 2016 and 2017 respectively with 2017 yield significantly lower than either previous years (LSD $1.79 \mathrm{Mg} \mathrm{ha}^{-1}$ ).

Biomass yield was similar between 2015 and 2016. Twenty-fifteen was near normal for precipitation, 2016 dry and much warmer as indicated by GDD accumulation. Precipitation in 2016 was $37 \%$ of 2015 . Biomass yield was significantly different between 2016 and 2017. Both years were similar in GDD accumulation but precipitation in 2017 was $362 \%$ of 2016. Most of the July rain was received over a 14 day period. Neither disease incidence nor insect damage was observed in 2017 so we surmise that sunn hemp is not tolerant of wet or frequently saturated soils.

These results indicate that sunn hemp performs well under warm, dry conditions, an important attribute for summer cover crops which will be frequently subject to this situation under midwestern conditions. Long-term precipitation data indicate that July has the most variable precipitation and it is historically the warmest.

Planting date significantly affected biomass DM yield (Table 2) for the 2-year combined analysis as well as in the 3 year combined analysis of dates 2-4 (data not shown) in which the year $\mathrm{x}$ date interaction was not significant. While some intra-date intervals are not significantly different or are marginally so, there is a clear trend of declining yield as date gets progressively later to the point of no yield by the September date due to lack of germination and/or poor stands with unmeasurable growth. In a combined analysis, yield decline was linear. Relative yield decline from 15 June was significant $\left(\mathrm{R}^{2}=0.8090 * *\right)$, equating to $1.3 \% \mathrm{~d}^{-1}$ or $8.9 \%$ per week. Absolute yield decline $\left(\mathrm{R}^{2}=0.5793 * *\right)$ was $0.09 \mathrm{Mg} \mathrm{d}^{-1}$ or $0.61 \mathrm{Mg}$ per week.

Similar results have been reported by Balkcom et al. (2011) from experiments in Alabama. A photosensitive crop, sunn hemp responds to variation in GDD because of limited time for GDD during vegetative growth. Delaying planting by 4 weeks or longer from late March to mid-April in the Rio Grande Valley of Texas generally reduced biomass yield. Since most sunn hemp cultivars have short day flowering response, delays in planting will shorten the growing season and could result in lower stalk yields (Cook et al., 1998). As the planting date is delayed, fewer GDD accumulate, leading to a decline in the biomass DM accumulation.

These results clearly indicate the importance of early planting. We hypothesized that yield potential may remain relatively constant when planted earlier in the season, then eventually decline as observed in other species (Stute, 2000), but that was not the case in this study. Growers should carefully weigh yield potential with planting date when considering sunn hemp as a cover crop.

Biomass yield from Experiment II is reported in Table 3. Years are combined because the year $\mathrm{x}$ ratio interaction was non-significant. Seeding ratio had a significant effect on biomass yield, however, any ratio which contained sorghum-sudan was not significantly different from any of the others, only pure stands of sunn hemp. In pure stand, sunn hemp yielded $38.6 \%$ of sole sorghum-sudan, 5.55 vs. $14.37 \mathrm{Mg} \mathrm{ha}^{-1}$ and ratios were intermediate. The relative contribution of sunn hemp and sorghum-sudan to total DM yield is shown in Figure 1. While these 
contributions can't be analyzed statistically because of the unbalanced design, as the percentage of sorghum-sudan in the ratio increases, the contribution of sunn hemp decreases. We had hypothesized that sunn hemp would compete well with sorghum-sudan if they were of similar heights, but neither was the case and sorghum-sudan overtopped the canopy within 45 to 60 days after planting (DAP).

Table 3. Yield and estimated cost of production based on seed cost and yield

\begin{tabular}{|c|c|c|c|c|c|c|c|c|c|c|c|c|c|}
\hline \multirow{2}{*}{$\begin{array}{l}\text { Ratio } \\
\mathrm{SH} / \mathrm{SS}\end{array}$} & \multicolumn{4}{|c|}{ Total Yield } & \multicolumn{2}{|c|}{ Planting Rate } & \multicolumn{3}{|c|}{ Seed Cost ${ }^{t}$} & \multicolumn{4}{|c|}{ Cost per Unit of Production } \\
\hline & DM & $\mathrm{N}$ & $\mathrm{C}$ & $\mathrm{CO}_{2} \mathrm{Eq}$ & $\mathrm{SH}$ & SS & $\mathrm{SH}$ & SS & Total & $\mathrm{DM}$ & $\mathrm{N}$ & C & $\mathrm{CO}_{2} \mathrm{Eq}$ \\
\hline$(\%)$ & $\mathrm{Mg} \mathrm{ha}^{-1}$ & $\mathrm{~kg} \mathrm{ha}^{-1}$ & $\mathrm{tha}^{-1}$ & tha $^{-1}$ & \multicolumn{2}{|c|}{$-\mathrm{kg} \mathrm{ha}^{-1}-$} & - & $\$ \mathrm{ha}^{-1}$ & - & $\$ \mathrm{Mg}^{-1}$ & $\$ \mathrm{~kg}^{-1}$ & $\$ t^{-1}$ & $\$ t^{-1}$ \\
\hline $100 / 0$ & 5.55 & 97.0 & 2.17 & 7.95 & 33.6 & 0.0 & 125.97 & 0.00 & 125.97 & 22.68 & 1.30 & 57.99 & 15.84 \\
\hline $75 / 25$ & 12.17 & 161.9 & 4.78 & 17.49 & 25.2 & 8.4 & 94.48 & 15.93 & 110.41 & 9.07 & 0.68 & 23.12 & 6.31 \\
\hline $67 / 33$ & 11.67 & 159.4 & 4.57 & 16.74 & 22.5 & 11.1 & 84.40 & 21.03 & 105.43 & 9.03 & 0.66 & 23.09 & 6.30 \\
\hline $50 / 50$ & 13.40 & 165.7 & 5.42 & 19.83 & 16.8 & 16.8 & 62.99 & 31.86 & 94.85 & 7.08 & 0.57 & 17.51 & 4.78 \\
\hline $33 / 67$ & 12.98 & 175.8 & 5.10 & 18.69 & 11.1 & 22.5 & 41.57 & 42.70 & 84.27 & 6.49 & 0.48 & 16.52 & 4.51 \\
\hline $25 / 75$ & 12.86 & 172.9 & 5.07 & 18.58 & 8.4 & 25.2 & 31.49 & 47.79 & 79.29 & 6.17 & 0.46 & 15.64 & 4.27 \\
\hline $0 / 100$ & 14.37 & 182.4 & 5.93 & 21.75 & 0.0 & 33.6 & 0.00 & 63.73 & 63.73 & 4.44 & 0.35 & 10.74 & 2.93 \\
\hline \multirow[t]{2}{*}{$\operatorname{LSD}(0.05)$} & 3.20 & 48.3 & 1.43 & 5.22 & & & & & & & & & \\
\hline & \multicolumn{4}{|c|}{ 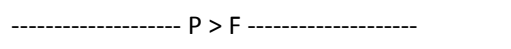 } & & & & & & & & & \\
\hline Year & 0.2379 & $<0.0001$ & $<0.0001$ & $<0.0001$ & & & & & & & & & \\
\hline Ratio & $<0.0001$ & 0.0202 & 0.0002 & 0.0002 & & & & & & & & & \\
\hline Ratio $x$ Year & 0.5607 & 0.4262 & 0.6893 & 0.6935 & & & & & & & & & \\
\hline \multicolumn{5}{|c|}{ t, Mean of 9 sources. } & & & & & & & & & \\
\hline
\end{tabular}
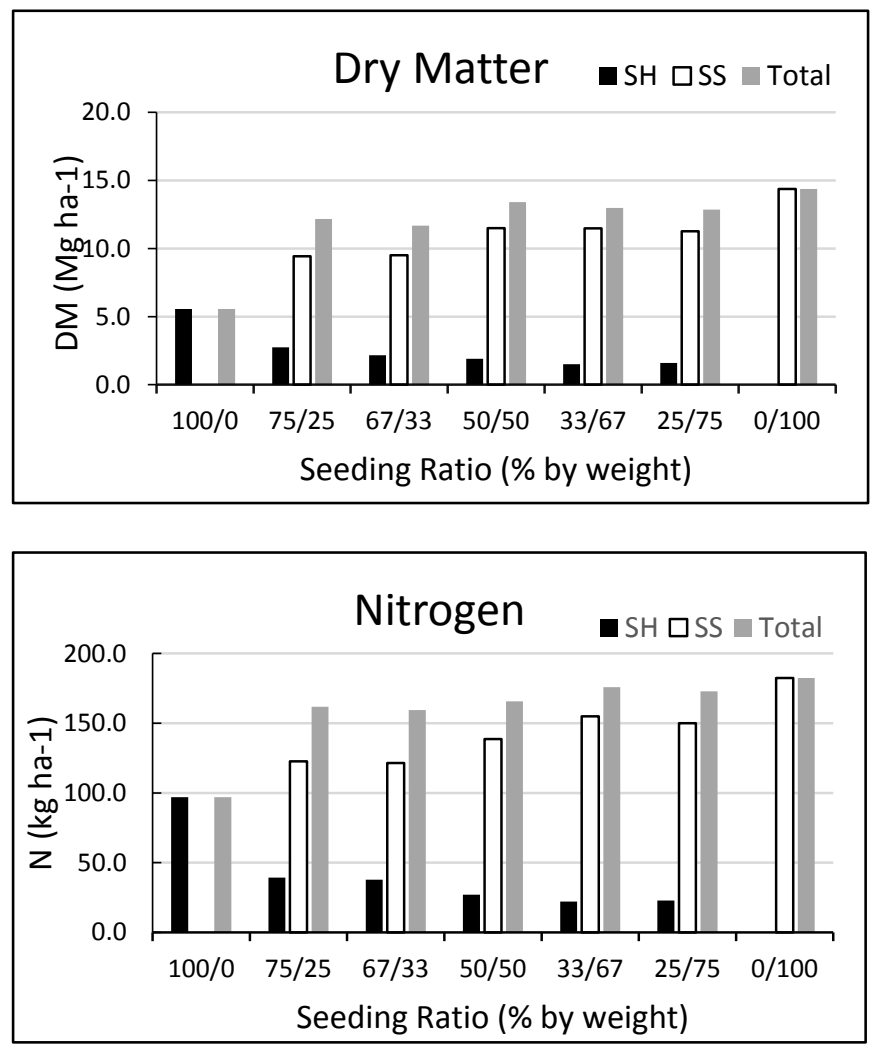

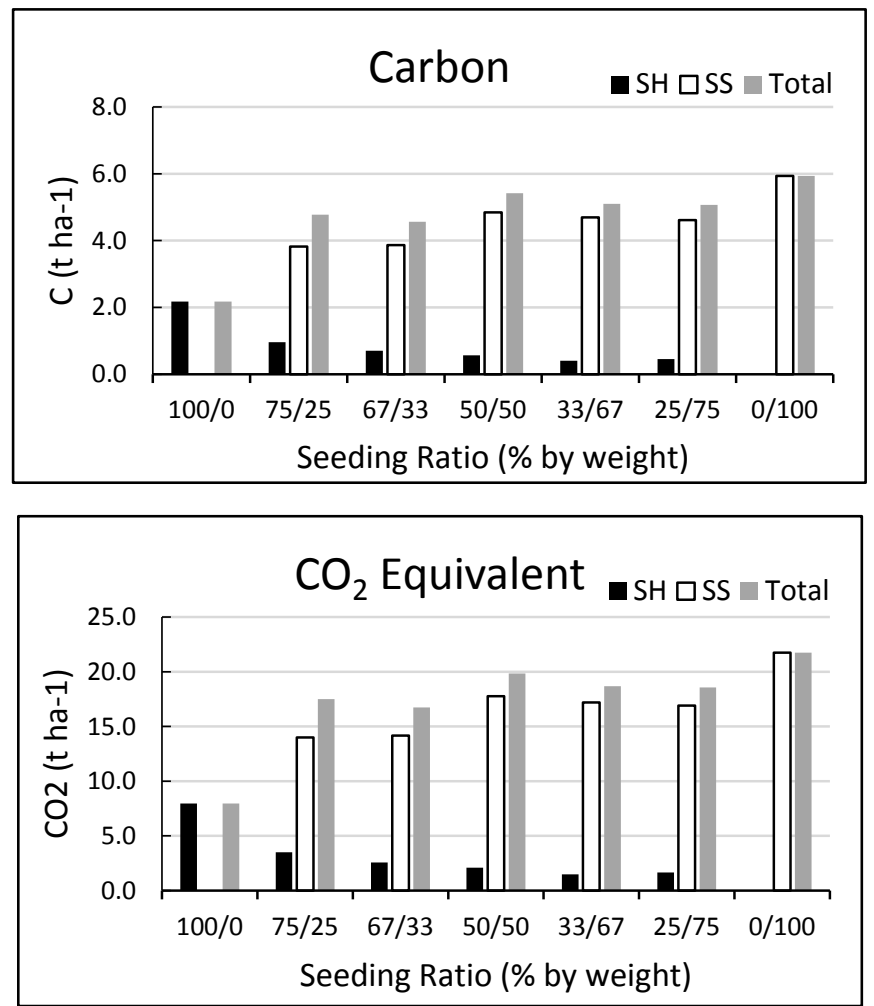

Figure 1. Biomass, Nitrogen, Carbon and $\mathrm{CO}_{2}$ Equivalent Yields with Sunn Hemp and Sorghum - Sudan in a biculture (combined analysis of three years 2014, 2016 and 2017)

Our main intent was not only to increase biomass DM yield per se, but also to reduce sunn hemp seed cost by using biculture, because of other desirable agronomic services, $\mathrm{N}$ fixation being the most important. In our opinion, the best combination for greatest biomass while adding fixed $\mathrm{N}$ is the 50:50 planting ratio (13.40 $\mathrm{Mg}$ $\mathrm{ha}^{-1} \mathrm{DM}$ yield). The data indicates that biomass accumulation did not vary significantly with any planting ratio. Under such conditions, the 50:50 ratio is considered advantageous because of reduced seed cost as well as the high biomass yield obtained, while also harvesting the other desirable services of sunn hemp. At the 50:50 planting ratio, sunn hemp contributed $14.2 \%$ while sorghum-sudan contributed $85.8 \%$ to the total (Fig. 1). Economic considerations are discussed later in the paper.

\subsection{Nitrogen and Carbon Content}

Biomass $\mathrm{N}$ and $\mathrm{C}$ followed the same general trends caused by treatment and environmental effects as DM in both experiments. This would be expected as both are DM components. In the case of $\mathrm{N}$ content, advancing planting date significantly reduced total, but unlike DM, $\mathrm{N}$ content for the first three planting dates was not significantly different (Table 2). This may be partially explained by changes in tissue $\mathrm{N}$ concentration over planting dates as older tissue had lower $\mathrm{N}$ concentration compared to younger tissue at sampling. In the combined 2016-2017 analysis, mean tissue $\mathrm{N}$ concentration for the first planting date was $14.7 \mathrm{~g} \mathrm{~kg}^{-1}$ compared to $23.3 \mathrm{~g} \mathrm{~kg}^{-1}$ for the fifth, nearly double $(1.86 \mathrm{x})$ and this increase was linear $\left(\mathrm{R}^{2}=0.6187^{* *}\right)$. It is possible that this increase in $\mathrm{N}$ concentration may have partially offset reduced DM. However, it is clear from the regression analysis that the decline in $\mathrm{N}$ content begins after the mid-June planting date which is also the case for C. Similar changes in $\mathrm{N}$ content with advancing planting date have been reported by Balkcom et al. (2011) and Stallings et al. (2017).

In biculture, $\mathrm{N}$ and $\mathrm{C}$ content increased with increasing percentage of sorghum-sudan in the mix and all ratios were significantly greater than the sole-seeded sunn hemp, but not sole-seeded sorghum-sudan (Table 3). Species ratio did not significantly affect tissue $\mathrm{N}$ or $\mathrm{C}$ concentration in either sunn hemp or sorghum-sudan (data not shown) so differences are solely due to DM yield. We assumed that $\mathrm{N}$ content in sunn hemp would include both fixed and soil $\mathrm{N}$, that in sorghum-sudan from soil and possibly from sunn hemp, and competition for soil $\mathrm{N}$ would cause sunn hemp to fix more $\mathrm{N}$ to meet its requirements. We did not measure soil $\mathrm{N}$ either prior to planting or post sampling so can't speculate on system $\mathrm{N}$ dynamics. Future biculture work should include these 
measurements.

With respect to added $\mathrm{C}$, all biculture ratios did not differ significantly. However, to weigh cost without compromising the agronomic and ecological services, the 50:50 ratio is probably optimal. Appelgate et al. (2017) reported similarly on cover crop mixed cultures for greater carbon addition. Contribution of sorghum-sudan to the total carbon added per hectare (Fig. 1) was $78.8 \%$, much greater than that of sunn hemp, when planted in a biculture planting ratio of 50:50.

\section{$3.3 \mathrm{CO}_{2}$ Equivalent}

$\mathrm{CO}_{2}$ equivalent was calculated from biomass $\mathrm{C}$ which is possible because all $\mathrm{C}$ in plant tissue comes from the atmosphere through photosynthesis (Stute, MFAI website). As such, it mirrors the same effects that affected C content in both experiments. We present this data with the intent of building on the literature database for use in future $\mathrm{C}$ credit crediting systems.

Studies have shown that cover crop effects on $\mathrm{CO}_{2}$ emissions or $\mathrm{CO}_{2}$ equivalents are linked to cover crop biomass production and are generally confined to its growing period (Ruis et al., 2018). Cover crops may not affect $\mathrm{CO}_{2}$ emissions during the growing season in temperate climates such as in the US Midwest and Central Great Plains (Negassa et al., 2015; Liebig et al., 2009). This carbon capture is not permanent but rather a strategy to take $\mathrm{CO}_{2}$ "out of play" in the short term. Some of it will be released rapidly as $\mathrm{CO}_{2}$ as residues decompose while the more stable forms will stay in soil for years, increasing SOM and improving soil health/ quality (Stute, MFAI website).

For cover crops to be an effective carbon sink, they need to be planted every year and the greater the planted acreage, the greater the presumed effect (Stute, MFAI Website). In addition to significant levels of C capture, it is interesting that several warm-season species and mixes do it in a relatively short timeframe compared to cool season crops (Stute unpublished). The sorghum-sudan, sunn hemp or biculture combination is planted from mid-June to early July and terminated by frost in mid-October. These cover crops would be used after shortseason crops, in situations where planting is prevented or as part of an organic soil improvement program (Esther $\&$ Stute, 2018). Studies have reported increased $\mathrm{CO}_{2}$ emissions under cover crops only when they increased SOC concentration (Kim et al., 2010; Haque et al., 2015).

Will sunn hemp, alone or in a biculture contribute to increased SOM or labile C? This needs to be determined experimentally. Sunn hemp C:N ratios for mid-June to early July establishment averaged 31.0, but ranged from 16.1 to 47.8 (median 31.5, SD 8.2) with higher ratios for the mid-June planting date (data not shown). Ratios are sufficiently high to expect slow decomposition and SOM addition. Differential $\mathrm{N}$ content between leaves and stalks has been reported (Marshal et al., 2002). We hypothesize that this differential will result in rapid decomposition of leaves and $\mathrm{N}$ mineralization, creating a pool of available $\mathrm{N}$ for the following crop while the higher C:N stalks will be more recalcitrant, adding to SOM. This idea warrants further investigation.

\subsection{Economic Index}

Experiment II examined biculture planting ratios to determine their effect on DM, N and C addition, and their suitability as companion crops to provide complementary benefits, reduce sunn hemp seed cost, and the per unit cost of production of output variables based on seeding rate and seed cost (Table 3 ). The seed cost data revealed that as the ratio of sunn hemp in the planting mixture decreased, seed cost per ha decreased, demonstrating that the main component of greater seed cost was that of sunn hemp as expected. However, the multiple ecosystem benefits accrued by growing sunn hemp including $\mathrm{N}$ fixation, possible SOM contribution and nematode suppression should be considered. The data suggests that for optimal DM, N and C production, the optimum sunn hemp: sorghum-sudan ratio is 50:50 based on per unit cost of production in the Midwest. The cost per unit production of dry matter, $\mathrm{N}, \mathrm{C}$ and $\mathrm{CO}_{2}$ equivalent at this planting ratio is $7.08 \$ \mathrm{Mg}^{-1}, 0.57 \$ \mathrm{~kg}^{-1}, 17.51 \$ \mathrm{t}^{-1}$ and $4.78 \$ \mathrm{t}^{-1}$, which though not the lowest, is similar and a compromise for capturing the ecological and agronomic services of sunn hemp.

\section{Conclusions}

Growing sunn hemp as cover crop provided high amounts of biomass DM, N and C and other associated benefits in the Midwest. Sunn hemp is a highly photosensitive crop and growth and biomass accumulation is greatly affected by GDD. It is very sensitive to planting date when grown as a warm season cover crop. Results from experiments conducted in Wisconsin have shown that planting sunn hemp from mid-June to early July is the most productive planting window, beyond which yield declines and per unit cost of production increases for Midwestern producers. The $\mathrm{CO}_{2}$ equivalents will also be greater only if sown during the recommended time frame. When opting for a biculture to reduce the cost of production for output variables, a 50:50 ratio appears to 
be the best option for optimal productivity and per unit cost of production. More studies are needed to develop a package of cultural practices for sunn hemp production and using these best management practices, quantify system benefits.

\section{Acknowledgements}

This work was partially funded by a USDA ARS Cooperative Agreement (58-5090-7-072). The authors gratefully acknowledge the assistance of Lauren Kazinski, Phil Klamm, Rylan McGuigan, Keegan Roamer and Rachel Stute with field work and sample processing. Mention of proprietary commercial products is for clarification only and does not imply endorsement by the authors or the Michael Fields Agricultural Institute.

\section{References}

Appelgate, S. R., Lenssen, A. W., Wiedenhoeft, M. H., \& Kaspar, T. C. (2017). Cover crop options and mixes for Upper Midwest Corn - Soybean Systems. Agronomy Journal, 109(3), 968-984. https://doi.org/10.2134/agronj2016.08.0453

Balkcom, K. S., \& Reeves, D. W. (2005). Sunn hemp utilized as a legume cover crop for corn production. Agronomy Journal, 97(1), 26-31. https://doi.org/10.2134/agronj2005.0026

Balkcom, K. S., Massey, J. M., Masjidis, J. S., Price, A. J., \& Enloe, S. F. (2011). Planting date and seeing rate effects on sunn hemp biomass and nitrogen production for a winter cover crop. International Journal of Agronomy, 5(3), 236-242.

Blanco-Canqui, H., Shaver, T. M., Lindquist, J. L., Shapiro, C. A., Elmore, R. W., Francis, C. A., \& Hergert, G. W. 2015. Cover Crops and Ecosystem Services: Insights from studies in temperate soils. Agron. J., 107, 2449-2474. https://doi.org/10.2134/agronj15.0086

Cherr, C. M., Scholberg, J. M. S., \& McSorley, R. (2006). Green manure as nitrogen source for sweet corn in a warm-temperate environment. Agronomy Journal, 98, 1173-1180. https://doi.org/10.2134/agronj2005.0036

Cook, C. G., Scott Jr., A. W., \& Chow, P. (1998). Planting date and cultivar effects on growth and stalk yield of sunn hemp. Industrial Crops and Products, 8(2), 89-95. https://doi.org/10.1016/S0926-6690(97)10013-9

Creamer, N. G., \& Baldwin, K. R. (2000). An evaluation of summer cover crops for use in vegetable production systems in North Carolina. HortScience, 35, 600-603. https://doi.org/10.21273/HORTSCI.35.4.600

Esthher, S. D., \& Stute, J. K. (2018). Sunn hemp: A legume cover crop with potential for the Midwest?. Sustainable Agriculture Research, 7(4), 63-69. https://doi.org/10.5539/sar.v7n4p63

Haque, M. M., Kim, S. Y., Ali, M. A., \& Kim, P. J. (2015). Contribution of greenhouse gas emissions during cropping and fallow seasons on total global warming potential in mono-rice paddy soils. Plant and Soil, 387, 251-264. https://doi.org/10.1007/s11104-014-2287-2

Kim, S. Y., Gutierrez, J., \& Kim, P. J. (2012). Considering winter cover crop selection as green manure to control methane emission during rice cultivation in paddy soil. Agriculture, Ecosystems and Environment, 161, 130-136. https://doi.org/10.1016/j.agee.2012.07.026

Liebig, M. A., Tanaka, D. L., \& Gross, J. R. (2010). Fallow effects on soil carbon and greenhouse gas flux in central North Dakota. Soil Sci. Soc. Am. J., 74, 358-365. https://doi.org/10.2136/sssaj2008.0368

Mansoer, Z., Reeves, D. W., \& Wood, C. W. (1997). Suitability of sunn hemp as an alternative late-summer legume cover crop. Soil Sci. Soc. Am. J., 61, 246-253. https://doi.org/10.2136/sssaj1997.03615995006100010034x

Marshall, A. J., Gallaher, R. N., Wang, K. H., \& McSorley, R. (2002). In: E. van Santen (ed.) 2002. Making conservation tillage conventional: Building a future on 25 years of research. Proc. Of $25^{\text {th }}$ Annual Southern Conservation Tillage Conference for Sustainable Agriculture. Auburn, AL 24-26 June 2002. Special Report No.1. Alabama Agric. Expt. Stn. And Auburn University, AL 36849, USA.

Michael Fields Agricultural Institute. (2019). Retrieved from http://michaelfields.org

Mosjidis, J. A., \& Wehtje, G. (2011). Weed control in sunn hemp and its ability to suppress weed growth. Crop Protection, 30(1), 70-73. https://doi.org/10.1016/j.cropro.2010.08.021

National Weather Service (2018). Retrieved from https://www.weather.gov/dlh/northlandfallfreezedates

Negassa, W., Price, R. F., Basir, A., Snapp, S. S., \& Kravchenko, A. (2015). Cover crop and tillage systems effect on soil $\mathrm{CO}_{2}$ and $\mathrm{N}_{2} \mathrm{O}$ fluxes in contrasting topographic positions. Soil Tillage Research, 154, 64-74. https://doi.org/10.1016/j.still.2015.06.015 
NRCS. (1999). Technical Note No.10, May 1999. Sunn Hemp: A cover crop for southern and tropical farming systems. Soil Quality - Agronomy Technical Note No. 10 Retrieved from https://www.nrcs.usda.gov/Internet/FSE_DOCUMENTS/nrcs142p2_053283.pdf

Price, A. J., Kelton, J., \& Mosjidis, J. (2012). Utilization of sunn hemp for cover crops and weed control in temperate climates. In Tech, 2012, 101-114.

Ruis, S., Blanco, K., Wortmann, C., \& Jin, V. (2018). Cover crop and CO2 emissions. Retrieved from https://cropwatch.unl.edu/2018/cover-crop-and-co2-emissions

SARE.org. (2018). Retrieved from https://www.sare.org/Learning-Center/Books/Managing-Cover-Crops-Profitably-3rd-Edition/Text-Version/ Nonlegume-Cover-Crops/Sorghum-Sudangrass

Schomberg, H. H., Martini, N. L., Diaz-Perez, J. C., Phatak, S. C., Balkcom, K. S., \& Bhardwaj, H. L. (2007). Potential for using sunn hemp as a source of biomass ad nitrogen for the piedmont and coastal plain regions of the south eastern USA. Agronomy Journal, 99, 1448-1457. https://doi.org/10.2134/agronj2006.0294

Stallings, A. M., Balkcom, K. S., Wood, C. W., Guertal, E. A., \& Weaver, D. B. (2017). Nitrogen mineralization from AU Golden sunn hemp residue. Journal of Plant Nutrition, 40(1), 50-62. https://doi.org/10.1080/01904167.2016.1193613

Stute, J. K. (2000). Cover crop options after corn silage. In Proc. 2000 Wisc. Fert. Ag lime and Pest Mgmt. Conf., 39, 419-424. Retrieved from https://extension.soils.wisc.edu/wcmc/cover-crop-options-after-corn-silage

Stute. MFAI Website. (2018). Retrieved from http://michaelfields.org/cover-crops-co2-and-carbon-credits

Wang, K. H., Sipes, B. S., \& Schmitt, D. P. (2002). Crotalaria as a cover crop for nematode management: A review. Nematropica, 32, 35-57.

Warren, J., Wilson, T., \& Edwards, J. (2017). Using sunn hemp as a cover crop in Oklahoma. Retrieved from https://www.southernsare.org/Educational-Resources/SARE-Project-Products/Fact-Sheets/Using-Sunn-Hem p-as-a-Cover-Crop-in-oklahoma

Yau, S. K., \& Hamblin, J. (1994). Relative yield as a measure of entry performance in variable environments. Crop Science, 34(3), 813-817. https://doi.org/10.2135/cropsci1994.0011183X003400030038x

\section{Copyrights}

Copyright for this article is retained by the author(s), with first publication rights granted to the journal.

This is an open-access article distributed under the terms and conditions of the Creative Commons Attribution license (http://creativecommons.org/licenses/by/3.0/). 